\title{
The influence of organic versus conventional feeding on the growth and survival of gilthead sea bream Sparus aurata $\mathrm{L}$. juveniles
}

\author{
María D. Ayala ${ }^{1 *}$, Antonio García-Saorín ${ }^{1}$, Helena Martínez-Torres ${ }^{1}$, \\ Alicia García-Alcázar ${ }^{2}$, and Marta Arizcun ${ }^{2}$

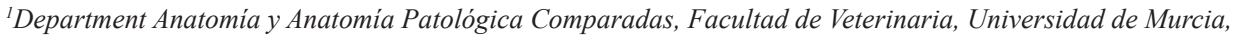 \\ Campus de Espinardo, Murcia, Spain \\ ${ }^{2}$ Centro Oceanográfico de Murcia, Instituto Español de Oceanografía, Puerto de Mazarrón. Murcia, Spain
}

\begin{abstract}
AYALA, M. D., A. GARCÍA-SAORÍN, H. MARTÍNEZ-TORRES, A. GARCÍAALCÁZAR, M. ARIZCUN: The influence of organic versus conventional feeding on the growth and survival of gilthead sea bream Sparus aurata L. juveniles. Vet. arhiv 89, 683-695, 2019.
\end{abstract}

\section{ABSTRACT}

Sparus aurata specimens of 11 months of age (mean weight: $90.2 \mathrm{~g}$, mean length: $18.3 \mathrm{~cm}$ ) were classified in two diet groups: one control group was fed with conventional diet, and one experimental group was fed with an organic diet. The body and muscle parameters were studied at 0,41 and 71 days of the experiment. The results showed the highest values of body length and weight as well as the best biological feed conversion rates in the organic group. The transverse area of white muscle, the hyperplasia and the muscle fibres density were also higher in the organic than in the conventional group $(\mathrm{P}>0.05)$. In contrast, hypertrophy was greater in the conventional than in the organic group $(\mathrm{P}<0.05)$. Survival was $100 \%$ in both groups. In conclusion, the organic feeding regime was more favourable for growth than conventional feeding.

Key words: Sparus aurata; organic diet; body growth; white muscle; muscle cellularity

\section{Introduction}

A market is emerging that demands healthy and environmentally friendly products. Along these lines organic or ecological aquaculture is also emerging, with food being one of the fundamental factors for obtaining ecological fish. Thus, organic feed must be composed of ingredients obtained in an ecological and sustainable way. TROCINO et al. (2012) studied the quality of organic and conventionally-farmed European sea bass (Dicentrarchus labrax). The biometric traits and texture were not affected by the rearing

\footnotetext{
*Corresponding author:

María Dolores Ayala, Universidad de Murcia, Facultad de Veterinaria, Department Anatomía y Anatomía Patológica Comparadas, 30100 Campus de Espinardo, Murcia, Spain, Phone: + 34868888 793; Fax: +34 868 884 147; E-mail: mdayala@um.es
} 
system. Nevertheless, the ratio of n-3 to n- 6 polyunsaturated fatty acids was significantly higher in organic than in conventional fish. MENTE et al. (2012) studied the effect of organic and conventional production methods on gilthead sea bream (Sparus aurata L.) specimens, from $10 \mathrm{~g}$ to $350 \mathrm{~g}$ (commercial size) in sea cages. The gilthead sea bream specimens were kept at densities of $4 \mathrm{~kg} / \mathrm{m}^{3}$ (organic) and $15 \mathrm{~kg} / \mathrm{m}^{3}$ (conventional) and were fed with organic food (45\% crude protein, $14 \%$ fat) or conventional feed ( $46 \%$ crude protein, $17 \%$ fat). At the beginning of the experiment there were no significant differences in the mean values of body weight between the two groups. At 5-7 months of the experiment, the organic group showed a statistically higher mean weight than the conventional group. At the end of the experiment, the final mean weight of the organic group was again higher in comparison to the conventional group, but they were not statistically significantly different.

In 2014, MARINO et al. compared the growth, welfare and quality traits of European sea bass and gilthead sea bream specimens farmed in sea cages from $11 \mathrm{~g}$ to the commercial size. Both species were reared according to conventional and organic production methods. The results showed the better growth performance of organic farmed fish. Morphological and chemical parameters were similar in organic and conventional gilthead sea bream, whereas lower perivisceral fat and lipid content were observed in organic sea bass. Lower levels of n-3 PUFA and n-3/n-6 FA were found in organic specimens than in conventionally-farmed fish, due to their higher content of linoleic acid, reflecting feed composition. Fish sensory characteristics and shelf life were similar in both organic and conventional groups.

Muscle growth involves the recruitment (hyperplasia) and subsequent increase in size (hypertrophy) of muscle fibres (WEATHERLEY et al., 1988). Fish muscle is plastic in its response to environmental conditions. The relative contribution of muscle fibres hypertrophy and hyperplasia to the total muscle growth varies according to endogenous and exogenous factors. Some of the most important external factors are: temperature (AYALA et al., 2000, 2001, 2003; JOHNSTON et al., 2011; GARCÍA DE LA SERRANA et al., 2012; CAMPOS et al., 2013a,b), the photoperiod (JOHNSTON et al., 2004), exercise training (JOHNSTON and MOON, 1980) and diet (WEATHERLEY et al., 1980; FAUCONNEAU et al., 1997). However, there are hardly any studies on the muscle cellularity of fish being fed with vegetable and organic diets, with some exceptions, such as the study by VALENTE et al. (2016) on Senegalese sole (Solea senegalensis). In this study, the full replacement of the animal protein by plant (100\% vegetable protein) resulted in fish with a smaller fiber size. Also, the texture of the steaks was influenced in fish fed with $100 \%$ vegetable protein, showing a "moderate" correlation with the fiber size. This study also showed an influence of the $100 \%$ vegetal diet on the expression of muscle growth related genes. 
In the present study, we studied the influence of organic food on the growth performance and muscle cellularity of sea bream juveniles. Moreover, the conversion rates and the survival are studied.

\section{Materials and methods}

Animals. This experiment was carried out with a population of juvenile specimens of Sparus aurata obtained in December 2016 from a stock of spawners adapted to captivity at the Instituto Español de Oceanografía (Centro Oceanográfico de Murcia, Mazarrón, Spain). 120 juvenile specimens (11 months of age) of $90.2 \mathrm{~g} \pm 0.86$ (mean weight \pm $\mathrm{SEM}$ ) and $18.3 \mathrm{~cm} \pm 0.07$ (mean lenght $\pm \mathrm{SEM}$ ) were randomly distributed into six tanks (3 tanks/group; 20 fish/tank). The volume of the tanks was 170 liters, with open circuit (250 liters/hour water renewal) and light intensity of 400 lux. The photoperiod was maintained similar to the natural photoperiod with artificial light (16L:8D). The rearing temperature was ambient temperature, which ranged between $16-17.5^{\circ} \mathrm{C}$ in December, $14-16{ }^{\circ} \mathrm{C}$ in January and February, and $15.5-17.5^{\circ} \mathrm{C}$ in March. The two groups were fed with two different diets: the control group (conventional group) received a commercial conventional feed (Dibaq company, Segovia, Spain). The experimental group (organic group) received an ecological (organic) feed (B- Nature Marin company, Lamballe Cédex, France). The size of the particles was $3 \mathrm{~mm}$ in both diets. Both groups were fed $\mathrm{ad}$ libitum 3 times a day. The composition of the conventional feed was: $45 \%$ protein, $20 \%$ fat, $2.8 \%$ cellulose, $8 \%$ ash, $13.3 \%$ Carbohydrates, $10 \%$ humidity, $1.8 \%$ calcium, $0.9 \%$ phosphorus, and $21.2 \mathrm{MJ} / \mathrm{Kg}$ gross energy. The content of vitamins and trace elements was: 7500 IU vitamin $A, 1000$ IU vitamin $\mathrm{D}_{3}, 160 \mathrm{ppm}$ vitamin $\mathrm{C}, 150 \mathrm{ppm}$ vitamin $\mathrm{E}$, $1.5 \mathrm{ppm} \mathrm{Cu}, 50 \mathrm{ppm} \mathrm{Zn}, 57 \mathrm{ppm} \mathrm{Mg}, 2$ ppm Fe, 15 ppm Mn, 15 ppm iodine, 0.2 ppm Se. The ingredients were: fish meal, oilseeds, cereal grains, fish oil, blood products, chicken meal, soybean oil and rapeseed, vitamins and minerals, antioxidant and antifungal. The composition of the ecological feed was: $45 \%$ protein, $17 \%$ fat; $1.1 \%$ cellulose, $10.8 \%$ ash, $18.1 \%$ carbohydrates, $8 \%$ humidity, $1.6 \%$ phosphorus, $20 \mathrm{MJ} / \mathrm{kg}$ gross energy. The vitamin content, amino acids and fatty acids per $\mathrm{kg}$ of food was: $10000 \mathrm{IU}$ vitamin A, $1750 \mathrm{IU}$ vitamin $\mathrm{D}_{3}, 250 \mathrm{mg}$ vitamin C, $200 \mathrm{mg}$ vitamin E, 3\% lysine, $1.35 \%$ Methionine + Cystine, $3.9 \%$ omega $3,0.8 \%$ omega 6 , and $3.33 \%$ EPA + DHA. The ingredients were: fish meal, organic wheat, organic soybean cake, fish oils, organic peas, amino acids coproducts, premix, and vitamins.

The sampling was carried out on the following days of the experiment: day 0 (11-month old specimens before being classified into two different diets); day 41 and day 71 of the experiment, with 12.4- and 13.4-month old specimens, respectively. The body parameters (length and weight) were measured in all the fish (120) throughout of the experiment. In relation with the muscle parameters, the number of fish measured were: 10 fish (day 0), 12 fish/group (4/tank) (day 41) and 12 fish/group (4 fish/tank) (day 71). 
The feed conversion rates (total amount of feed consumed by fish/final weight initial weight of the fish) were calculated for both groups on days 41 and 71 . In the present study, the cost of the feed was: 0.95 euros $/ \mathrm{kg}$ for the control feed and 1.57 euros $/ \mathrm{kg}$ for the organic feed. In order to calculate the profitability of the feed, the economic conversion rates were calculated with the following formula: food conversion rate $\times$ euros per $\mathrm{kg}$ of food. The survival percentage was calculated at the end of the experiment.

At each sampling point, the specimens being used for muscle analysis were euthanized by overdose with clove oil at $60 \mathrm{ppm}$, and then delivered to the Veterinary Faculty of Murcia. This experiment was evaluated and approved by the Ethical Committee of Animal Experimentation of the University of Murcia (Spain), where the work was carried out. This experiment complies with current regulations (RD 53/2013) by which the use of animals for experimentation for other scientific and/or teaching purposes is regulated, Law 32/2007 for the protection of animals that are used for experimentation and for others scientific purposes, and Ministerial Order ECC/566 for the training of people working with experimental animals.

Quantitative analysis of the muscle growth. In order to analyse the muscle parameters, the specimens were cut transversely to the long body axis at the level of the anal opening and then whole body slices of $5 \mathrm{~mm}$ thickness were obtained. The whole cross muscle sections from each fish were photographed for measurement by a morphometric analysis system (Sygma-Scan Pro_5). Subsequently, these body slices were cut into smaller blocks and then snap frozen in 2-methylbutane over liquid nitrogen. Later on, $\approx$ ten sections of $8 \mu \mathrm{m}$ thickness were obtained from each specimen at $-20{ }^{\circ} \mathrm{C}$ in a cryostat (Leica $\mathrm{CM}$ 1850). Subsequently, the sections were stained with hematoxylin/eosin and photographed with an image analysis device (Qwin, Leica) connected to a light photomicroscope (Leitz Dialux, 20). The best samples of each specimen were selected and then 8 to 10 fields of each specimen were photographed. Muscle growth was quantified by means of the morphometric analysis system cited above (Sygma-Scan Pro_5). The following parameters were measured: total cross sectional area of the white muscle; number of white muscle fibres; size (area and minor axis length) of white muscle fibres and muscle fibre density (number of white fibres $/ \mathrm{mm}^{2}$ ). The average size was estimated from $\sim 600$ fibres $( \pm 10 \mathrm{SD})$ located in the intermediate and the apical sectors of the epaxial quadrant of the transversal section of the myotome, according to the methodology described by AYALA et al. $(2013,2015)$ in other species, such as shi drum (Umbrina cirrosa, L.).

Statistical analysis. The statistical analysis was performed with Statistical Package SPSS 19.0. The mean and standard error of the mean (SEM) were calculated from each group of data. Data distribution was analysed at each stage by the Shapiro-Wilk test for $\mathrm{P}<0.05$. In relation to the size of the fibres, the data did not show normal distribution $(\mathrm{P}<0.05)$ and Levene's test did not show homogeneous variances $(\mathrm{P}<0.05)$ either. Hence, 
nonparametric tests were used (Mann-Whitney and Kolmogorov-Smirnov tests) to evaluate the effect of the diet on the size of the fibres, for $\mathrm{P}<0.05$. For most of the other parameters, both tests (Shapiro-Wilk and Levene) showed values of $\mathrm{P}>0.05$ and hence, the analysis of variance (ANOVA) was used. However, nonparametric tests were used in the cases with values of $\mathrm{P}<0.05$.

\section{Results}

Body growth, conversion rates and survival. At the beginning of the experiment (day 0 ), the specimens were 11 months old. The mean weight and the mean total body length values $\pm \mathrm{SEM}$ of these specimens were $90.2 \pm 0.86 \mathrm{~g}$ and $18.3 \pm 0.07 \mathrm{~cm}$, respectively (Table 1).

Table 1. Values of fibrillar and body parameters in both feeding groups

\begin{tabular}{|l|c|c|c|c|c|}
\hline \multirow{2}{*}{ Age } & $\begin{array}{c}11 \text { months } \\
\text { (Day 0) }\end{array}$ & \multicolumn{2}{|c|}{$\begin{array}{c}\text { 12.4 months } \\
\text { (Day 41) }\end{array}$} & \multicolumn{2}{c|}{$\begin{array}{c}\text { 13.4 months } \\
\text { (Day 71) }\end{array}$} \\
\hline Feeding regime & & $\begin{array}{c}\text { Conventional } \\
\text { group }\end{array}$ & $\begin{array}{c}\text { Organic } \\
\text { group }\end{array}$ & $\begin{array}{c}\text { Conventional } \\
\text { group }\end{array}$ & $\begin{array}{c}\text { Organic } \\
\text { group }\end{array}$ \\
\hline Body lenght $(\mathrm{cm})$ & $18.3 \pm 0.1$ & $19.3^{\mathrm{a}} \pm 0.1$ & $19.3^{\mathrm{a}} \pm 0.1$ & $20.1^{\mathrm{a}} \pm 0.1$ & $20.4^{\mathrm{a}} \pm 0.1$ \\
\hline Body weight $(\mathrm{g})$ & $90.2 \pm 0.9$ & $105.5^{\mathrm{a}} \pm 1.5$ & $106.8^{\mathrm{a}} \pm 1.6$ & $117.7^{\mathrm{a}} \pm 2.4$ & $125.1^{\mathrm{b}} \pm 2.7$ \\
\hline $\mathrm{B}\left(\mathrm{mm}^{2}\right)$ & $556.2 \pm 19.6$ & $620^{\mathrm{a}} \pm 23.82$ & $634.8^{\mathrm{a}} \pm 22.1$ & $598.7^{\mathrm{a}} \pm 30.3$ & $678.7^{\mathrm{a}} \pm 42.1$ \\
\hline $\mathrm{A}\left(\mu \mathrm{m}^{2}\right)$ & $3645.2 \pm 42.2$ & $3846.3^{\mathrm{a}} \pm 48.7$ & $3444.6^{\mathrm{b}} \pm 28.3$ & $3581.4^{\mathrm{a}} \pm 29.9$ & $3340.5^{\mathrm{b}} \pm 28.5$ \\
\hline $\mathrm{D}(\mu \mathrm{m})$ & $55.6 \pm 0.4$ & $56^{\mathrm{a}} \pm 0.3$ & $55^{\mathrm{b}} \pm 0.2$ & $55.4^{\mathrm{a}} \pm 0.3$ & $52.1^{\mathrm{b}} \pm 0.2$ \\
\hline $\mathrm{N}$ & 153100.4 & $173631^{\mathrm{a}}$ & $187937.7^{\mathrm{a}}$ & $168760.7^{\mathrm{a}}$ & $205469.1^{\mathrm{a}}$ \\
& \pm 5824.3 & \pm 13114.6 & \pm 9477.7 & \pm 9504 & \pm 14051.4 \\
\hline Dens & 277.6 & $278.7^{\mathrm{a}}$ & $298.6^{\mathrm{a}}$ & $282.4^{\mathrm{a}}$ & $302.8^{\mathrm{a}}$ \\
& \pm 13.9 & \pm 16.8 & \pm 16.3 & \pm 8.8 & $\pm 8.7^{2}$ \\
\hline
\end{tabular}

Mean values \pm SEM; $B$ - cross-sectional area of the white muscle; A - white muscle fibres area; D - minor axis length; N - number of white fibres; Dens - density (number of fibers $/ \mathrm{mm}^{2}$ ). Different superscripts in each row indicate significant differences $(\mathrm{P}<0.05)$ among both feeding groups for each stage of age.

At 41 days of the experiment (12.4 month old specimens), the body length and body weight values were similar in both groups $(\mathrm{P}>0.05)$ (Table 1). At this stage, the mean values \pm SEM of the feed conversion rates were $2.79( \pm 0.2)$ versus $2.09( \pm 0.15)$ in the conventional and organic groups, respectively. The economic conversion rates were as follows: $2.79 \times 0.95=2.65$ euros $/ \mathrm{kg}$ for the conventional feed; and $2.09 \times 1.57=3.29$ euros/ $\mathrm{kg}$ for the organic feed. At 71 days of the experiment (13.4 months old specimens), the body values (length and weight) were higher in the organic than in the conventional group, significantly for the weight $(\mathrm{P}<0.05)$. At this stage, the conversion rate values were $3.55( \pm 0.38)$ and $2.16( \pm 1.67)$ in the conventional and organic groups, respectively $(\mathrm{P}<0.05)$. The economic conversion rates were: $3.55 \times 0.95=3.37$ euros $/ \mathrm{kg}$ for the 
conventional feed; and $2.16 \times 1.57=3.40$ euros $/ \mathrm{kg}$, for the organic feed. The percentage of survival was $100 \%$ in both groups at the end of the experiment.

Muscle growth. On day 0, all the parameters were obtained from specimens reared under the same rearing conditions from hatching until the beginning of the experiment. Fig. 1 shows the muscle transverse sections of several specimens from both feeding groups (ecologic and conventional) on day 0 (Fig. 1 a, b); day 41 (Fig. 1 c, d) and day 71 (Fig. 1 e, f). In all cases the muscle showed a morphological mosaic, with small fibres interposed among large fibres.

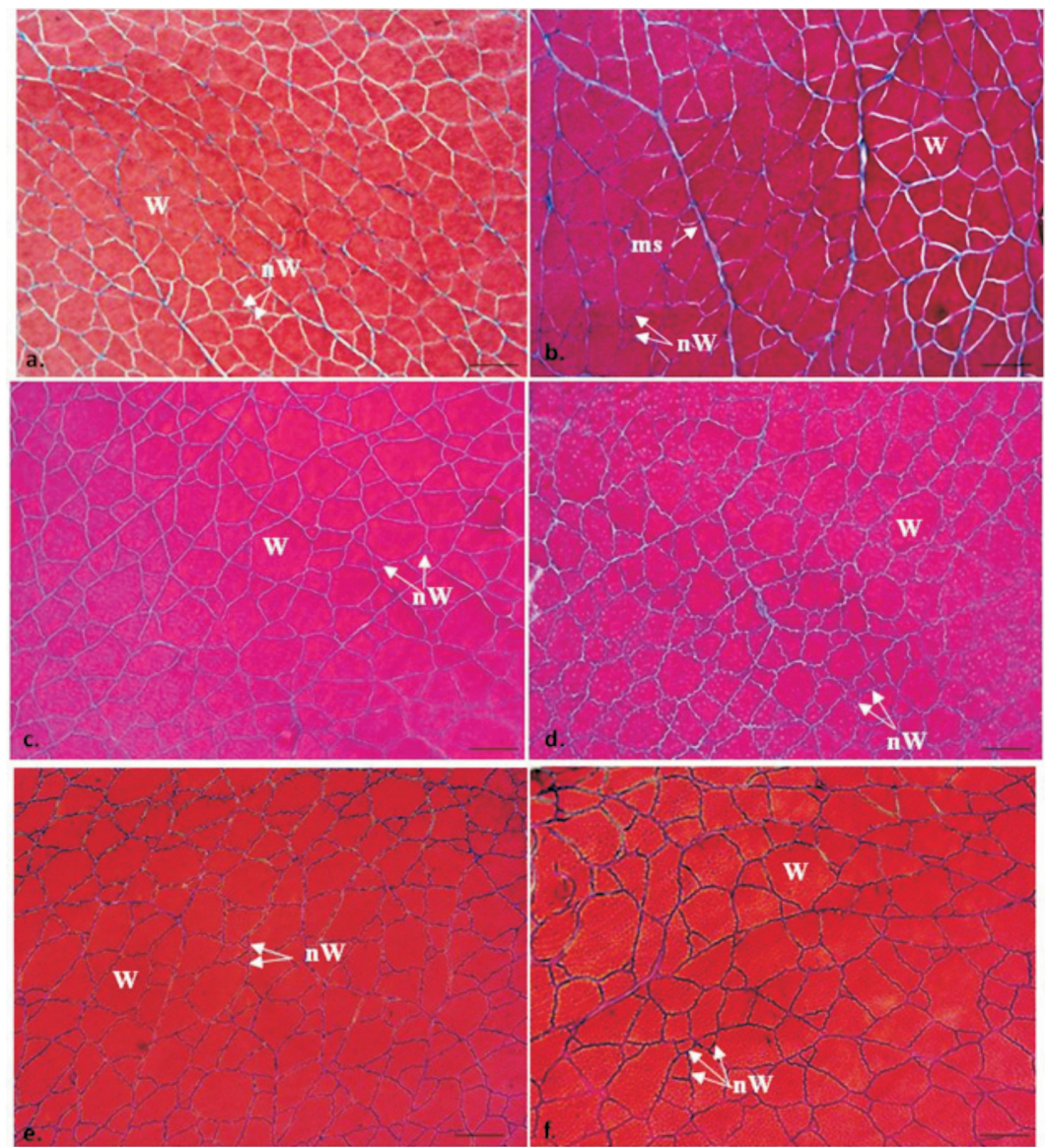

Fig. 1. Transverse white muscle sections of Sparus aurata specimens of $11(\mathrm{a}, \mathrm{b}), 12.4$ (c,d) and $13.4(\mathrm{e}, \mathrm{f})$ months of age from the conventional $(\mathrm{a}, \mathrm{c}, \mathrm{e})$ and the ecological $(\mathrm{b}, \mathrm{d}, \mathrm{f})$ groups; W - white muscle fibres; $\mathrm{nW}$ - new white muscle fibres. ms - myosept. H\&E; scale bars $=100 \mu \mathrm{m}$. 
Table 1 shows the mean muscle parameters throughout the experiment in both groups. At 41 days of the experiment, the highest values of the cross-sectional area of the white muscle were reached in the organic group. Similarly, the hyperplasia and the muscle fibre density were higher in the organic than in the conventional group (Fig. 1c,d; Table 1). In contrast, the highest muscle hypertrophy values were reached in the conventional group $(\mathrm{P}<0.05)$ (Table 1).

At 71 days of the experiment, the muscle parameters showed the same tendency as in the previous stage, with the highest hyperplasia in the organic group, but with the highest hypertrophy in the conventional group (Table 1; Fig. 1e,f).

\section{Discussion}

Influence of the diet on the body growth and on the conversion rates. The results of the present experiment indicate the positive effect of the organic food on the body growth and the efficiency in the conversion of the food. The formulation of the two feeding regimes was not exactly the same (to see material and methods). Thus, conventional food has a higher fat percentage than organic food, while the organic food has a higher content of vitamins and essential fatty acids than the conventional regime. However, we believe that the higher efficiency of the organic feed compared with the conventional feed must be mainly due to the quality of the nutrients, because of their organic origin. The ingredients of the organic feed are produced without synthetic chemicals (pesticides, fertilizers, medicines, etc.) and without the addition of artificial substances (additives, dyes, flavours, aromas, etc.). In addition, they are obtained with respect for the rhythm of growth of plants and animals. Therefore, the ingredients of organic feed are healthier than those obtained with a conventional feed. This, together with the different percentages of the components mentioned above between the two feeds, could justify the differences in the efficiency of both feeds. However, more studies should be done to confirm this hypothesis.

Other authors (MENTE et al., 2012) compared the growth of S. aurata specimens in both rearing systems (conventional and organic) throughout their production cycle and found that, in the middle of the fattening period, the organic group showed higher growth and lower fat than the conventional group. However, when both groups reached the commercial size, these differences were not significant. On the other hand, MARINO et al. (2014) also observed greater growth in S. aurata and D. labrax specimens maintained under organic conditions than those being reared under conventional conditions. On the other hand, in these studies (MENTE et al., 2012; MARINO et al., 2014) the rearing conditions included different factors. Thus, not only the feeding regime was different (organic versus conventional), but also the density of cultivation was lower in the organic 
groups than in the conventional ones. In the present study, the density was similar in all the tanks $\left(8.4-10.5 \mathrm{~kg} / \mathrm{m}^{3}\right)$.

Nowadays, organic feed is more expensive than conventional feed. This fact, together with the legal requirements for organic farming (low fish density, etc.), usually increases the cost of this type of production (LÓPEZ, 2013). In the present study, the rate of economic conversion was initially worse for the organic than for the conventional feed, but at the end of the experiment these rates were similar. This indicated similar profitability for both types of feed under the conditions of this experiment.

Influence of the diet on muscle growth. In relation to the muscular parameters, the results show the muscular plasticity of the teleosts under different environmental conditions, as has been observed in this and other species (JOHNSTON et al., 2003; JOHNSTON, 2006; AYALA et al., 2013, 2015; AYALA et al., 2016). In general, hypertrophy is associated with slower growth than hyperplasia (HIGGINS and THORPE, 1990; VEGGETTI et al., 1990). Thus, the results of the present study show that the organic group showed a typical fast growing muscle constitution, with a higher fibre generation than the conventional group. On the contrary, the conventional group presented slower growth than the organic group, with greater fibrillar hypertrophy than the organic group.

On the other hand, the plasticity of the muscle cellularity under different environmental conditions can persist and produce long-term effects (AYALA et al., 2001; JOHNSTON et al., 1998, 2003, 2004; IMSLAND et al., 2007; STEINBACHER et al., 2011; GARCÍA DE LA SERRANA et al., 2012; CAMPOS et al., 2013b). Hence, the differences in the muscular cellularity between the organic and the conventional groups in the present study may determine differences in the subsequent growth of both groups. Thus, the organic group, with higher fibrillar density and greater hyperplasia, seems to present greater growth potential than the conventional group. However, this hypothesis should be confirmed by more specific techniques to identify the existence and expression of myogenic stem cells (myogenic precursors). Also, the differences in muscle cellularity could be maintained in the long term, thus producing a persistent effect in the fillet. The lasting effect is usually observed in teleosts that have been maintained in different environmental conditions during the early stages of their life. For example, different external factors, such as the temperature (STEINBACHER et al., 2011; AYALA et al., 2016) during the early stages of life exert a thermal imprinting on muscle cellularity throughout the advanced stages of life due to the lasting $\mathrm{T}$ effects on myogenic cell precursor (MPC) proliferation (STEINBACHER et al., 2011).

In general, there is a positive correlation between fibre density and firmness (HATAE et al., 1984, 1990). PERIAGO et al. (2005) compared specimens of cultured and wild sea bass and found a smaller fibrillar size in the wild specimens, together with a greater firmness of the fillet. In other studies in Senegal sole (Solea senegalensis), VALENTE et 
al. (2016) observed that the use of $100 \%$ vegetable protein significantly reduced the size of the fibres and the transverse area of the white muscle of the individuals fed with this diet, whereas the hyperplasia was not influenced.

According to the results and their comparison with other studies, we believe that it is necessary to extend these studies for a longer time in order to verify their long-term effect on the growth dynamics and the final quality of the product. The results can be of interest for the producers in order to optimize production efficiency.

\section{Conclusions}

The most optimal diet for body and muscle growth was the organic feed, so that the values of length and body weight, as well as the value of the transverse area of the white muscle were higher in the organic than in the conventional group. The muscle cellularity was different in the two feeding groups. Thus, hypertrophy was greater in the conventional than in the organic group, thus reflecting the typical muscular constitution of slow growth, whereas hyperplasia was greater in the organic than in the conventional group, thus showing the muscular constitution typical of the fast growth. These differences could persist in the long term, influencing the subsequent growth of both groups and the final texture of the fillet. However, longer studies are needed in order to observe the dynamics of long-term growth and its influence on the final quality of the product.

\section{Ethical Statements}

Compliance with ethical standards.

\section{Conflicts of interest}

The authors declare that they have no conflict of interest.

\section{Acknowledgements}

This work was made possible by collaboration between the Instituto Español de Oceanografía and the Universidad de Murcia. We appreciate the collaboration of ANDROMEDA IBERICA company, which provided the organic food for this work.

\section{References}

AYALA, M. D., O. LÓPEZ-ALBORS, F. GIL, R. LATORRE, J. M. VÁZQUEZ, A. GARCÍAALCÁZAR, E. ABELLÁN, G. RAMÍREZ, F. MORENO (2000): Temperature effect on muscle growth of the axial musculature of the sea bass (Dicentrarchus labrax L.). Anat. Histol. Embryol. 29, 235-241.

AYALA, M. D., O. LÓPEZ-ALBORS, F. GIL, A. GARCÍA-ALCÁZAR, E. ABELLÁN, J. A. ALARCÓN, M. C. ÁLVAREZ, G. RAMÍREZ-ZARZOSA, F. MORENO (2001): Temperature 
effects on muscle growth in two populations (Atlantic and Mediterranean) of sea bass. Aquaculture 202, 359-370.

DOI: $10.1016 / \mathrm{S} 0044-8486(01) 00785-2$

AYALA, M. D., O. LÓPEZ-ALBORS, A. GARCÍA-ALCÁZAR, E. ABELLÁN, R. LATORRE, J. M. VÁZQUEZ, G. RAMÍREZ- ZARZOSA, F. GIL (2003): Effect of two thermal regimes on the muscle growth dynamics of sea bass, Dicentrarchus labrax L. Anat. Histol. Embryol. 32, 271-275.

AYAlA, M. D., E. ABELlÁN, M. ARIZCUN, A. GARCÍA-ALCÁZAR, F. NAVARRO, A. BLANCO, O. LÓPEZ-ALBORS (2013): Muscle development and body growth in larvae and early postlarvae of shi drum, Umbrina cirrosa L., reared under different larval photoperiod. Muscle structural and ultrastructural study. Fish Physiol. Biochem. 39, 807-827.

DOI: $10.1007 / \mathrm{s} 10695-012-9742-\mathrm{X}$

AYALA, M. D., M. ARIZCUN, A. GARCÍA-ALCÁZAR, M. SANTAELLA, E. ABELLÁN (2015): Long-term effects of the larval photoperiod on the subsequent growth of shi drum Umbrina cirrosa L. specimens and the fillet texture at commercial size. Turk. J. Fish Aquat. Sci. 15, 93-101.

DOI:10.4194/1303-2712-v15_1_10

AYALA, M. D., J. HERNÁNDEZ-URCERA, M. SANTAELLA, R. CAL (2016): Lasting temperature effects on the muscle tissue, body growth and fillet texture of adult turbots, Scophthalmus maximus, L. J. World Aquacult. Soc. 47, 759-767.

DOI: 10.1111 /jwas. 12298

CAMPOS, C., L. M. P. VALENTE, L. E. C. CONCEIÇÃO, S. ENGROLA, J. M. O. FERNANDES (2013a): Temperature affects methylation of the myogenin putative promoter, its expression and muscle cellularity in Senegalese sole larvae. Epigenetics 8, 389-397.

DOI: $10.4161 /$ epi.24178

CAMPOS, C., J. M. O. FERNANDES, L. E. C. CONCEIÇÃO, S. ENGROLA, V. VOUSA, L. M. P. VALENTE (2013b): Thermal conditions during larval pelagic phase influence subsequent somatic growth of Senegaleses sole by modulating gene expression and muscle growth dynamics. Aquaculture 414-415, 46-55.

DOI:10.1016/j.aquaculture.2013.07.039

FAUCONNEAU, B., S. ANDRE, J. CHMAITILLY, P. Y. LE BAIL, F. KRIEG, S. J. KAUSHIK (1997): Control of skeletal muscle fibres and adipose cells in the flesh of rainbow trout. J. Fish Biol. 50, 296-314.

DOI: $10.1111 / j .1095-8649.1997 . t b 01360 . x$

GARCÍA DE LA SERRANA, D., V. L. A. VIEIRA, K. B. ANDREE, M. DARIAS, A. ESTÉVEZ, E. GISBERT, I. A. JOHNSTON (2012): Development temperature has persistent effects on muscle growth responses in gilthead sea bream. Plos One 7, 1-11.

DOI: 10.1371/journal.pone.0051884 
HATAE, K., F. YOSHIMATSU, J. J. MATSUMOTO (1984): Discriminative characterization of different texture profiles of various cooked fish muscles. J. Food Sci. 49, 721-726.

DOI: $10.1111 / j .1365-2621.1984 . t b 13195 . x$

HATAE, K., F. YOSHIMATSU, J. J. MATSUMOTO. (1990): Role of muscle fibres in contributing firmness of cooked fish. J. Food Sci. 55, 693-696.

DOI: $10.1111 / j .1365-2621.1990 . t b 05208 . x$

HIGGINS, P. J., J. E. THORPE (1990): Hyperplasia and hypertrophy in the growth of skeletal muscle in juvenile Atlantic salmon (Salmo salar, L.). J. Fish Biol. 37, 505-519.

DOI: $10.1111 / j .1095-8649.1990 . t b 05884 . x$

IMSLAND, A. K., A. FOSS, R. KOEDIJK, A. FOLKVORD, S. O. SREFANSSON, R. M. JONASSEN. (2007): Persistent growth effects of temperature and photoperiod in Atlantic cod Gadus morhua. J. Fish Biol. 71, 1371-1382.

DOI: 10.1111/j.1095-8649.2007.01600.x

JOHNSTON, I. A. (2006): Environment and plasticity of myogenesis in teleost fish. J. Exp. Biol. 209, 2249-2264.

DOI: $10.1242 /$ jeb.02153

JOHNSTON, I. A., T. W. MOON. (1980): Endurance exercise training in the fast and slow muscles of a teleost fish (Pollachius virens). J. Comp. Physiol. 135, 147-156.

JOHNSTON, I. A., N. J. COLE, M. ABERCROMBY, V. L. A. VIEIRA (1998): Embryonic temperature modulates muscle growth characteristics in larval and juvenile herring. J. Exp. Biol. 201, 623-646.

JOHNSTON, I. A., S. MANTHRI, A. SMART, P. CAMPBELL, D. NICKELL, R. ALDERSON (2003): Plasticity of muscle fibres number in seawater stages of Atlantic salmon in response to photoperiod manipulation. J. Exp. Biol. 206, 3425-3435.

DOI: $10.1242 /$ jeb.00577

JOHNSTON, I. A., S. MANTHRI, R. BICKERDIKE, A. DINGWALL, R. LUIJKX, P. CAMPBELL, D. NICKEL, R. ALDERSON (2004): Growth performance, muscle structure and flesh quality in out-of-season Atlantic salmon (Salmo salar) smolts reared under two different photoperiod regimes. Aquaculture 237, 281-300.

DOI: 10.1016/j.aquaculture.2004.04.026

JOHNSTON, I. A., N. I. BOWER, D. J. MACQUEEN (2011): Growth and the regulation of myotomal muscle mass in teleost fish. J. Exp. Biol. 214, 1617-1628.

DOI: $10.1242 /$ jeb.038620

LÓPEZ, M. D. (2013). Ecological aquaculture in the marine environment: a practical case of production in the Mediterranean. Culmarex group. Notebooks for agrifood studies (in spanish). ISSN 2173-7568. Spain, pp. 51-60.

MARINO, G. P., P. DI MARCO, T. PETOCHI, M. G. FINOIA, P. TOMASSETTI, S. PORRELLO, G. PARISI, G. GIORGI, M. LAZZARO, B. M. POLI (2014): Organic versus conventional 
M. D. Ayala et al.: Organic diet influence on Sparus aurata

sea bass and sea bream cage farming. Aquaculture Europe Congress. 14-17 October, San Sebastián, Spain. pp. 771-772.

MENTE, E., A. STRATAKOS, I. S. BOZIARIS, K. A. KORMAS, V. KARALAZOS, I. T. KARAPANAGIOTIDIS, V. A. CATSIKI, L. LEONDIADIS (2012): The effect of organic and conventional production methods on sea bream growth, health and body composition: a field experiment. Sci. Mar. 76, 549-560.

DOI: $10.3989 /$ scimar.03411.07C

PERIAGO, M. J., M. D. AYALA, O. LÓPEZ-ALBORS, I. ABDEL, C. MARTÍNEZ, A. GARCÍAALCÁZAR, G. ROS, F. GIL (2005): Muscle cellularity and flesh quality of wild and farmed sea bass, Dicentrarchus labrax L. Aquaculture 249, 175-188.

DOI: 10.1016/j.aquaculture.2005.02.047

STEINBACHER, P., J. MARSCHALLINGER, A. OBERMAYER, A. NEUHOFER, A. M. SÄNGER, W. STOIBER (2011): Temperature-dependent modification of muscle precursor cell behaviour is an underlying reason for lasting effects on muscle cellularity and body growth of teleost fish. J. Exp. Biol. 214, 1791-1801.

DOI: $10.1242 /$ jeb.050096

TROCINO, A., G. XICCATO, D. MAJOLINI, M. TAZZOLI, D. BERTOTTO, F. PASCOLI, R. PALAZZI (2012): Assesing the quality of organic and conventionally-farmed European sea bass (Dicentrarchus labrax). Food Chem. 131, 427-433.

DOI: 10.1016/j.foodchem.2011.08.082

VALENTE, L. M. P., E. M. CABRAL, V. SOUSA, L. M. CUNHA, J. M. O. FERNANDES (2016): Plant protein blends in diets for Senegalese sole affect skeletal muscle growth, flesh texture and the expression of related genes. Aquaculture 453, 77-85.

DOI: 10.1016/j.aquaculture.2015.11.034

VEGGETTI, A., F. MASCARELLO, P. A. SCAPOLO, A. ROWLERSON (1990): Hyperplastic and hypertrophic growth of lateral muscle in Dicentrarchus labrax (L.): an ultrastructural and morphometric study. Anat. Embryol. 182, 1-10.

DOI: $10.1007 / \mathrm{bf00187522}$

WEATHERLEY, A. H., H. S. GILL, S. C. ROGERS (1980): The relationship between mosaic muscle fibres and size in rainbow trout (Salmo gairdneri). J. Fish Biol. 17, 603-610.

DOI: 10.1111/j.1095-8649.1980.tb02792.x

WEATHERLEY, A. H., H. S. GILL, A. F. LOBO (1988): Recruitment and maximal diameter of axial muscle fibres in teleosts and their relationship to somatic growth and ultimate size. J. Fish Biol. 33, 851-859.

DOI: 10.1111/J.1095-8649.1988.TB05532.X

Received: 9 April 2018

Accepted: 22 May 2019 


\begin{abstract}
AYALA, M. D., A. GARCÍA-SAORÍN, H. MARTÍNEZ-TORRES, A. GARCÍAALCÁZAR, M. ARIZCUN: Utjecaj organske i konvencionalne prehrane na rast i preživljavanje mlađi komarče Sparus aurata L. Vet. arhiv 89, 683-695, 2019. SAŽETAK

Ribe vrste Sparus aurata u dobi od 11 mjeseci (prosječna masa 90,2 g, prosječna dužina 18,3 cm) podijeljene su u dvije skupine: kontrolnu hranjenu uobičajenom hranom i pokusnu hranjenu organskom hranom. Tjelesni i mišićni pokazatelji analizirani su nulti, 41. i 71. dan pokusa. Rezultati su pokazali najveće vrijednosti tjelesne dužine i mase, kao i najbolje stope konverzije hrane u skupini hranjenoj organskom hranom. Transverzalno područje bijelog mišića, hiperplazija i gustoća mišićnih vlakana također su imali veće vrijednosti u pokusnoj skupini u odnosu na kontrolnu $(\mathrm{P}>0,05)$. Za razliku od toga hipertrofija je bila veća u kontrolnoj skupini $(\mathrm{P}<0,05)$. Preživljenje je u obje skupine bilo $100 \%$. Na temelju ovih rezultata možemo zaključiti da je organska prehrana prikladnija za rast od konvencionalne prehrane.
\end{abstract}

Ključne riječi: Sparus aurata; organska prehrana; porast tjelesne mase; bijeli mišić; mišićna celularnost 
